\title{
USE OF CORRELATION-REGRESSION ANALYSIS FOR ESTIMATION OF PROSPECTS OF NATURAL GAS EXTRACTION OF SHALE ROCKS
}

\author{
Olga Lebega \\ Department of enterprise economy \\ Ivano-Frankivsk National Technical University of Oil and Gas \\ 15 Karpatska str., Ivano-Frankivsk, Ukraine, 76019 \\ o.lebega@ecointel.com.ua \\ Yaroslav Vytvitsky \\ Department of enterprise economy \\ Ivano-Frankivsk National Technical University of Oil and Gas \\ 15 Karpatska str., Ivano-Frankivsk, Ukraine, 76019 \\ 59471@tvnet.if.ua
}

\begin{abstract}
The article uses a correlation-regression analysis to further use the obtained correlation dependencies to assess the prospects for the extraction of natural gas from slate rocks in any region of the world. The statistical data on which correlation dependencies are derived are collected by analyzing information on the experience of shale gas extraction in countries such as the United States Marcellus, Haynesville, Barnett, Fayetteville, Woodford, Antrim, New Albany, Canada, Montenegro, Horn River), China - playground Fuling and Argentina - the playground Vaca Muerta. Characteristics of shale formations are investigated for each of these deposits: gas content, depth intervals of shale rock formation, effective thickness, porosity, penetrability, organic matter content, catagenesis, wells productivity.

Keywords: natural gas from slate rocks, resources, characteristics of shale formations, correlation-regressive dependencies, estimation of productivity of gas wells in slate formations.
\end{abstract}

\section{Introduction}

Under modern conditions of the world economy development mathematical methods are widely used for estimating and prognosticating economic processes. The large number of existent factors in oil-gas extraction sphere conditions the necessity of using a multiple correlation-regression analysis for a quantitative estimation of interdependencies between numerous statistical parameters that characterize separate geological-physical properties of oil-gas promising formations and economic characteristics of hydrocarbons extraction from them. At the analysis it is necessary to establish the theoretical form of the connection between factor and effective signs (regression analysis) and to determine the closeness of this connection (correlation analysis) that is to calculate quantitatively and to estimate the interaction mechanism of studied factor signs.

The received results of the correlation-regressive analysis may be used to ground managerial decisions as to prognostication and planning of volumes of natural gas extraction from shale rocks and their economic estimation at new promising plots.

\section{Analysis of literary data and statement of problem}

In the monograph [1] are described fundamental bases of a regression analysis and also methods of construction and study of models of different complication levels, with an analysis of practical aspects of their use. But these authors didn't consider possibilities of using a correlation-regression analysis for estimating and prognosticating prospects of natural gas extraction from shale rocks.

The principles of modeling at using a correlation-regression analysis and prognostication models using Microsoft Excel are presented in the work [2]. In this study we used Microsoft Excel possibilities, described by these authors to construct correlation-regression models between main geological and economic characteristics of slate formations. 
The study is devoted to problems of natural gas extraction from shale [3]. This work describes the main parameters of slate formations and gives the detail characteristics of the main playgrounds of the USA - Barnett, Fayetteville, Haynesville, Marcellus, Woodford, and also playgrounds Horn River and Mounteney of Canada. These characteristics were used by us at constructing correlation-regression dependencies.

The analysis of prospects of natural gas extraction is given in the publication [4]. This work also presents the main parameters of gas-shale playgrounds of the USA, used in this study.

The estimation of shale hydrocarbons developing on the example of Bakken, Eagle Ford, Barnett, Haynesville, Fayetteville, Marcellus formations is presented in the paper [5]. This work gives the detail characteristic of the productivity (outputs) of gas wells, dynamics of their changes that was the important information at choosing correspondent geological parameters for the statistical analysis.

The grounded analysis of hydrocarbons deposits in shale rocks is given in the bibliographic review [6]. There are presented most significant playgrounds of shale gas of the USA, Canada, Brazil, Argentina and several other countries, based on the analysis of more than forty literary sources that is used by us at generalizing information that became a base for the correlation-regression dependencies construction.

The article [7] is devoted to prospects of shale gas use as a global resource. In this work is realized the analysis of world reserves of shale gas and given the characteristics of slate basins of Northern and Southern America, Europe, Africa, China, India, Pakistan and Australia. The most detail characteristic was given to the slate formation of Argentina - Vaca-Muerta that is used in this study.

The feature of slate formations is a high changeability of geological characteristics of area and excavation that conditions the presence of highly productive zones, so called "sweet spots". The paper [8] is devoted just to the substantiation of criteria for searching for such highly productive zones. The data about characteristics of these highly productive zones are used by us as maximal values of geological parameters of separate slate formations, for example Woodford.

The leader of the "shale revolution" in the USA is Marcellus formation that contains the larg-

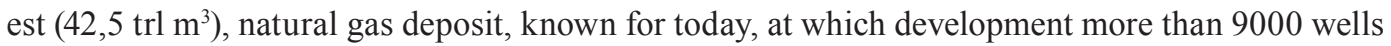
were bored, and which provides almost $40 \%$ of shale gas extraction in the USA. The analysis of geological and economic characteristics of this unique deposit is presented in the work [9], which results are used in this study.

Today China occupies the second place in the world by volumes of shale gas extraction. The analysis of characteristics of slate formations of Sichuan and Tamir sedimentary basins is presented in the thesis [10]. Characteristics of Fuling deposit and wells of Lonmasi layer were used at the correlation dependencies construction.

The first European country that began geological surveys and shale gas extraction was Poland. There is concentrated, probably, the most potential as to shale gas among European countries. Baltic and Lublin basins of Silurian age, connected to the trans-European break zone are extended along the whole country, from the North of its central part to the Southern East. According to existent sources of information, in Poland were bored more than 50 wells with the following results: Lewino-1G2, placed in the North of Poland, near Gdansk city 5,663-11,327 thousand of $\mathrm{m}^{3} /$ day [11]; Lebien LE-2H, placed in Pomor province, near Lebork city, demonstrated the best result for today $-15,4$ thousand of $\mathrm{m}^{3} / \mathrm{day}$. [12]. These data were also used by us as base ones at the statistical analysis.

Our analysis of gas extraction from shale rocks gave a possibility to establish the most important characteristics of slate formations that became a base for the correlation-regression analysis [13].

But none of the considered works [3-13] tries to use the correlation-regression analysis for the further use of correlation dependencies to predict the main geo-economic characteristics of natural gas deposits in slate formations. 


\section{Aim and tasks of research}

The aim of research is the establishment of economic-mathematical models to estimate the productivity of gas extracting wells depending on different factors to predict geo-economic characteristics of reservoirs in slate formations at new territories, areas and local objects.

The following tasks were set for attaining the set aim:

1. To receive and to study pair correlations between the productivity (output) of gas wells and geological characteristics of slate formations.

2. To receive and to study multidimensional correlations between the productivity (output) of gas wells and geological characteristics of slate formations.

3. To establish and to study the correlation between the price of break-even gas extraction and the productivity of slate wells.

\section{Materials and methods}

To solve the set problems, we used data about geological and economic characteristics of slate formations that natural shale gas is extracted from successfully for today.

The main methods of the study were statistical processing of information, disperse, correlation and regression analysis.

\section{Results of research}

The analysis of the foreign experience as to the prospecting and extraction of gas from shale rocks, especially of countries, where its industrial extraction is realized for today, given by us in the work [13], gave a possibility to establish the most important characteristics of slate formations, namely:

- content of the organic matter (kerogen), \%;

- thermal maturity of shale rocks (catagenesis degree $\mathrm{R}^{\circ}$ ), \%;

- porosity, $\%$;

- effective thickness of the productive horizon, $\mathrm{m}$;

- penetrability, nanodarcy;

- bedding depth, m;

- gas content, $\mathrm{m}^{3} / \mathrm{t}$.

These characteristics became a precondition for constructing correlation dependencies that help to receive the qualitative estimation of most prospective zones for gas extraction and to determine economic parameters of such zones, in first turn, productivity (output) of gas wells.

At the first stage the study of statistical characteristics of selected parameters was realized [14]. The character of their distribution, change limits, mathematical expectation, standard deviation were established. The correlation-regression analysis of such pair dependencies between characteristics of slate formations and gas wells output was realized.

The content of the organic matter in shale rocks (Fig. 1). The main criterion of the difference of gas slates from other sedimentary rocks is the content of the organic matter (kerogen). The content of the organic matter in the slate mass is distributed by the normal law and changes within $0,46-20 \%$, the mean value $-4,88 \%$, the standard deviation is $4,04 \%$ [14]. As it is shown by numerous studies, the content of the organic matter in promising zones must exceed $1-3 \%$ [8]. The increased content of the organic matter also favors the renewal of gas reserves.

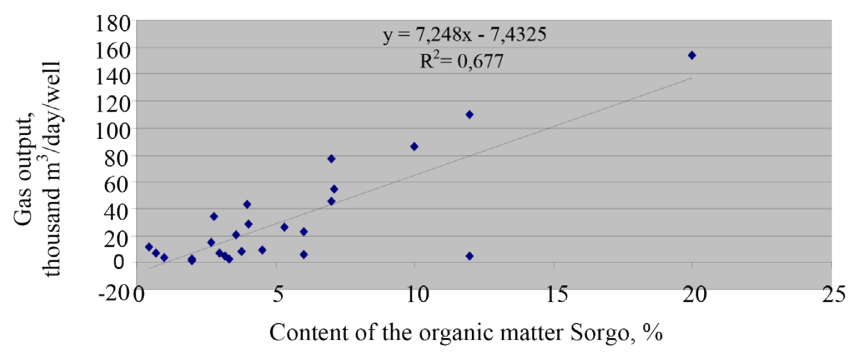

Fig. 1. Dependence between the output of Qg well and content of the organic matter Sorgo 
Catagenesis degree of the organic matter (Fig. 2). The degree of catagen transformations of the organic matter is determined by the reflecting capacity of vitrinite (Ro). In general, the increase of the level of catagen transformation that is the level of thermal maturity of the organic matter is attended with the increase of carbon in kerogen, so Ro value grows. At essential bedding depths and under conditions of a high pressure, it provides essential initial gas outputs. Ro value is distributed by the normal law, changes within $0,4-5 \%$, the mean value $-1,88 \%$, the standard deviation $-1,09 \%$.

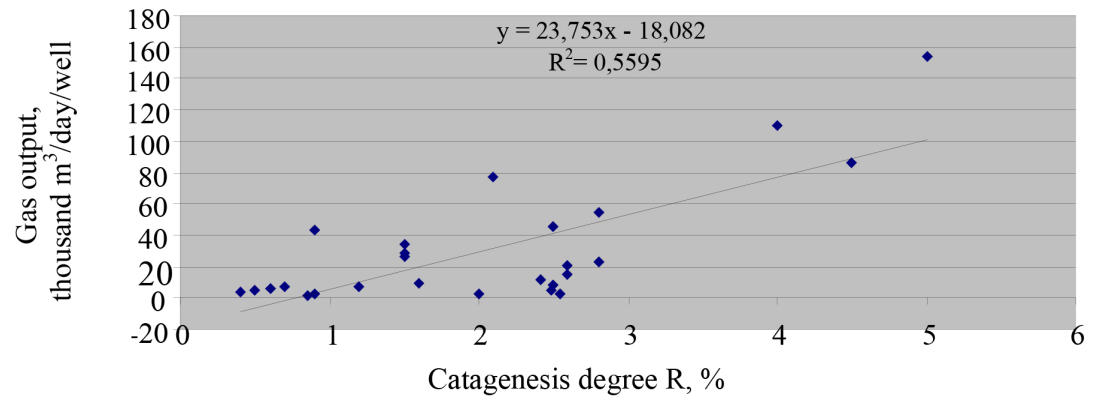

Fig. 2. Dependence between the output of Qg well and kerogen catagenesis degree $\mathrm{R}^{\circ}$

Porosity (Fig. 3). Local highly productive zones of shale masses are characterized with the high matrix porosity. Pores in shale rocks contain a lot of shale gas that in initial periods of extraction may be gotten with high outputs that favor the improvement of economic parameters of the prospecting. The porosity of shale masses changes within $0,5-14 \%$, the mean value $-6,39 \%$, the standard deviation $-3,73 \%$. As it can be seen on Fig. 3, the dependence between the porosity and output has the nonlinear character and is described by the exponential function.

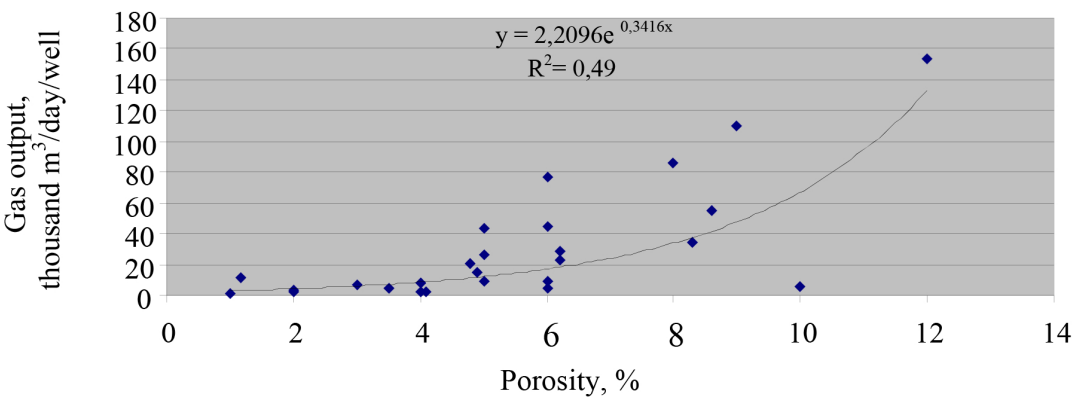

Fig. 3. Dependence between the output of Qg well and porosity of $\mathrm{K} \Pi$ shale rocks

Effective thickness of the slate mass (Fig. 4). Slates thickness together with the large area of their distribution and presence of the organic matter for gas adsorbing determines shale gas reserves and also creates more favorable conditions for the boring of the horizontal part of wells. Our analysis showed that the effective thickness of slate masses changes by the normal law within 6-350 $\mathrm{m}$, the mean value $-85,8 \mathrm{~m}$, the standard deviation is $76,8 \mathrm{~m}$.

Penetrability of shale rocks (Fig. 5). Penetrability is a characteristic that determines filtration properties of shale rocks. The great importance is inherent to the system of natural cracks, conditioned by schistosity, that determine the penetrability and increase the productivity of GPP, because the existence of natural cracks favors the spread and development of artificial cracks systems. Shale rocks penetrability is distributed by the lognormal law, widely changes within 5-5000 nanodarcies, the mean value is 679 nanodarcies, the standard deviation is 1399 nanodarcies.

Depth of shale rocks bedding (Fig. 6). The depth of shale mass bedding as a geological factor essentially influences the choice of technical, technological and organizational decisions at boring wells, developing deposits and also is an important factor of the formation of investment costs 
and cost price of gas extraction. From the other side, with the increase of shale masses bedding depth, bedded pressures and temperature grow that favors the deepening of catagenesis degree of the organic matter and increase of wells productivity. The depth of shale masses bedding changes within $122-4378 \mathrm{~m}$, the mean value $-2088 \mathrm{~m}$, the standard deviation is $1131 \mathrm{~m}$. The character of this dependence is also nonlinear.

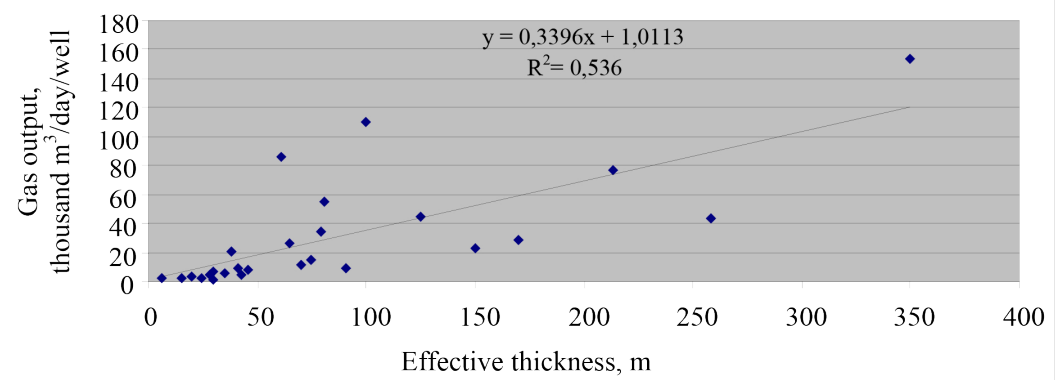

Fig. 4. Dependence between the output of Qg well and effective thickness of shale rocks hef

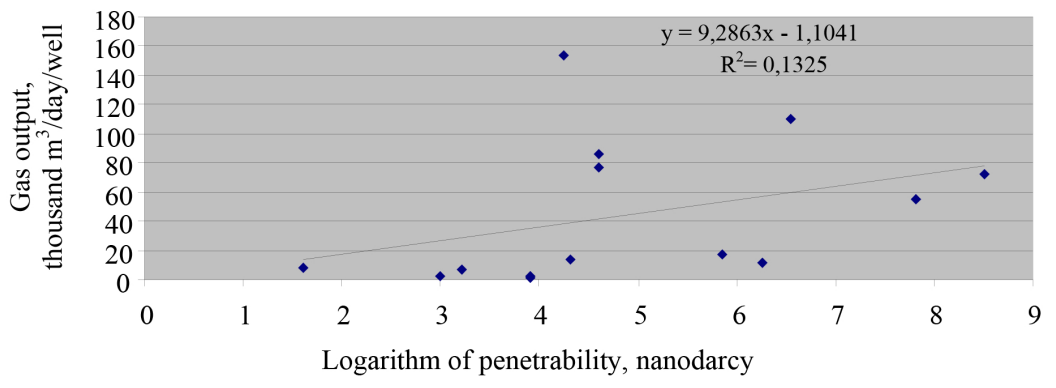

Fig. 5. Dependence between the output of Qg well and logarithm of shale rocks lnKpr

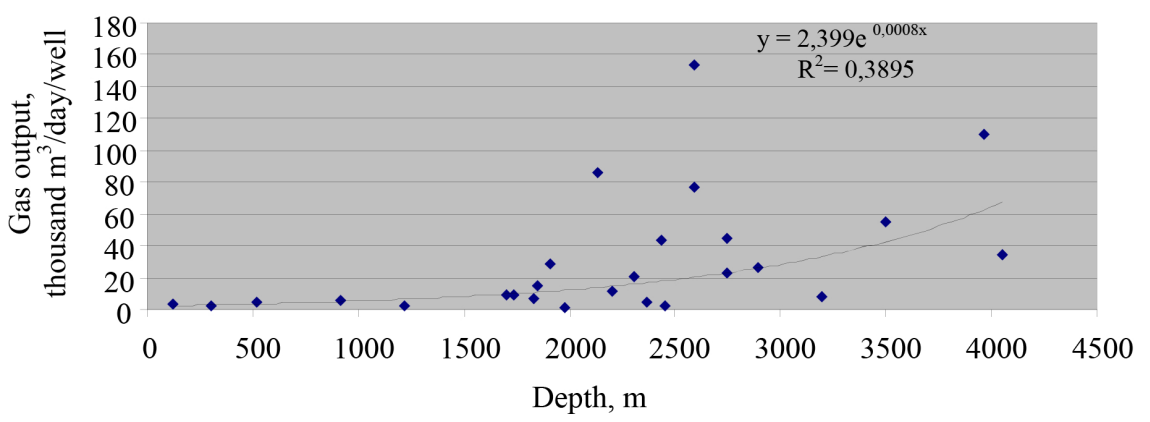

Fig. 6. Dependence between the output of Qg well and shale rocks H bedding depth

Gas content (Fig. 7). The realized analysis of the gas content in shale masses of the world showed that it is distributed by the normal law and changes within $0,44-9,9 \mathrm{~m}^{3} / \mathrm{t}$, the mean value $4,58 \mathrm{~m}^{3} / \mathrm{t}$, the standard deviation $-2,88 \mathrm{~m}^{3} / \mathrm{t}$.

As it is demonstrated by the presented CRA results, all received pair correlation-regression dependencies are significant and prove the geo-physical essence of interconnection between studied parameters.

It is well-known, that it is possible to establish more exact and reliable connections between studied parameters using multifactorial correlation-regression analysis [1, 2]. Just this task was the following stage of the research, in which result the following dependencies between the gas output from wells in shale rocks and most important geological characteristics of these rocks were received $(1,2)$ :

$$
\mathrm{Qg}=-34,54+3,74 \text { Sorgo }+9,06 \mathrm{Ro}+0,4 \mathrm{Kn}+0,14 \mathrm{hef}+0.006 \mathrm{H}
$$


$\mathrm{Rm}=0,94$; Volume of sample -26 observations; $\mathrm{Fr}=28,64>\mathrm{Fcr}=2,01$.

$$
\mathrm{Qg}=-29,35+3,44 \text { Sorg+4,38 Kp+0,17 hef }+1,95 \text { ln Kpr; }
$$

$\mathrm{Rm}=0,91 ;$ Volume of sample -14 observations; $\mathrm{Fr}=11,26>\mathrm{Fcr}=3,34$.

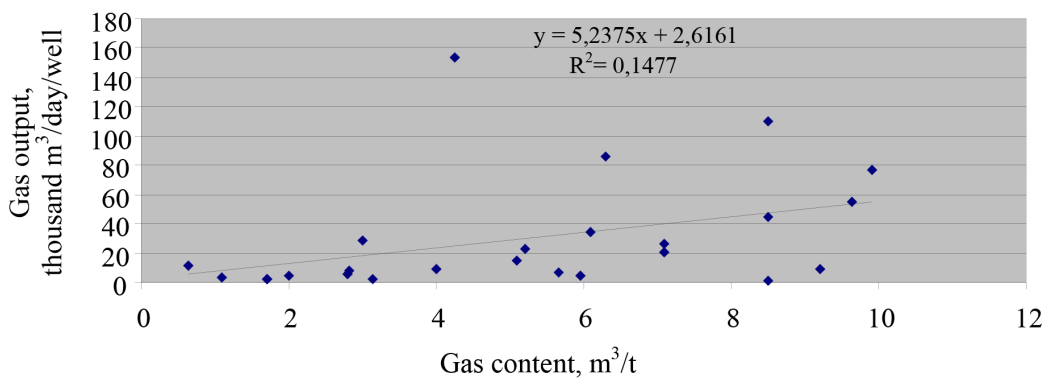

Fig. 7. Dependence between the output of Qg and gas content $\mathrm{Cg}$

The received dependencies are characterized by the highly close connection that is proved by coefficients of multiple correlation $\mathrm{Rm}-0,91-0,94$ and high exceed of critical values of Fisher criterion.

It is necessary to note, that the received dependencies have the important practical value, because they allow to predict the most important geological parameter of shale rocks - prognosticated output of shale wells. Alongside with it, these dependencies give a possibility to estimate the quality of boring and prospecting of shale rocks by the comparison of prognosticated and real outputs of wells.

Finally, at the last stage of research was set the correlation dependency between the price of the break-even gas extraction on the initial output of wells (Fig. 8), based on data of the main deposits of the USA (Barnett, Fayetteville, Haynesville, Marcellus, Woodford), presented in the work [15].

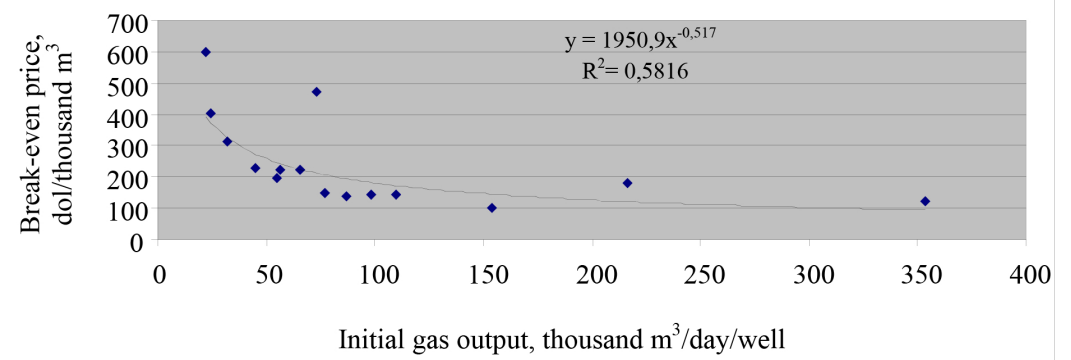

Fig. 8. Dependence between the break-even shale gas extraction on the wells output

As it is shown on Fig. 8, this dependence has the nonlinear character and is well described by the power function. This dependence gives a possibility to predict the limit of the well productivity, at which shale gas extract may be break-even.

\section{Discussion of results}

The advantage of these studies is the use of correlation-regression analysis methods to establish the character and closeness of dependencies between most important geological and economic parameters of slate formations that the industrial extraction of shale gas is realized from.

The received dependencies give a possibility to prognosticate the wells productivity and limit of the break-even shale gas extraction at any plots of shale deposits that is a base of the successful management of geological surveys and shale deposits developing.

These studies are the continuation of ones on the analysis of the world experience of shale gas extraction and methodical approaches to the estimation of the productivity of investment projects, connected with natural gas extraction from shale rocks. 
Further studies will be directed on the specification and improvement of correlation-regression dependencies at receiving additional information about geo-economic characteristic of shale rocks in new promising regions and deposits of shale gas.

\section{Conclusions}

As a result of the studies:

1. The pair correlation dependencies between the shale wells productivity and content of the organic matter, degree of its catagen transformation, porosity, effective thickness, penetrability, bedding depth, gas content were received.

2. The multidimensional correlation-regression dependencies between the shale wells productivity and most important geological characteristics of shale playgrounds were received.

3. The correlation dependence between the shale wells productivity and limit of costs, at which the break-even shale gas extraction is possible, was received.

The use of the received correlation-regression dependencies may be a push for estimating prospects of the natural gas extraction from shale deposits in different sedimentary basins of the world and Ukraine.

\section{References}

[1] Dreiper, N. (2007). Prikladnoi regressionnyi analiz. Moscow: Izdatelskii dom «Vilyams», 912.

[2] Mur, D., Uyederford R., Yellen, G., Guld, F., Shmidt, Ch. (2004). Ekonomicheskoe modelirovanie v Microsoft Excel. Moscow: Izdatelskii dom «Vilyams», 1024.

[3] Dmitrievskij, A. N., Vysockij, V. I. (2010). Slancevyj gaz - novyj vektor razvitiya mirovogo rynka uglevodorodnogo syrya. Gazovaya promyshlennost, 8, 44-47.

[4] Sorokin, S. N., Goryachev, A. A. (2012). Osnovnye problemy i perspektivy dobychi slancevogo gaza. Moscow, 12. Available at: https://www.eriras.ru/files/Sorokin_Goryachev_OEPEE_slanec.pdf

[5] Cvetkov, L. D., Cvetkova, N. L. () Slancevye uglevodorody. Yaroslavl, 2012. Available at: http:// ftp.nedra.ru/rus/activity/archive/publications/hydrocarbons.pdf

[6] Yurova, M. P. (2016). Distinctive Features of Shale Hydrocarbons Development in the United States (on the example of formations Bakken, Eagle Ford, Barnett, Haynesville, Fayetteville, Marcellus). Georesursy, 18(1), 38-45. doi:10.18599/grs.18.1.7 Available at: https://geors.ru/media/pdf/07_Yurova.pdf

[7] Boyer, Ch., Klark, B., Lis, R., Miller, K. K. (2011). Slancevyj gaz - globalnyj resurs. Neftegazovoe obozrenie, 23(3), 36-51.

[8] Glejzer. K. S., Miller, K. K., Dzhonson, G. M., Toll, B., Klyajnberg, R. L., Miller, P., Pennington, U. D. (2013). Poisk vysokoproduktivnyh zon: kachestvo kollektora i kachestvo zakanchivaniya skvazhin. Neftegazovoe obozrenie. Available at: http://www.slb.com/ /media/Files/resources/oilfield_review/russia13/ win13/article5.pdf

[9] Bogoyavlenskij V. I., Barinov, P., Bogoyavlenskij, I., Yakubson, K. (2016). Mestorozhdenie Marsellus - lider slancevoj revoljucii v USA. Available at: http://burneft.ru/archive/issues/2016-12/16

[10] Lyan, S. (2016). Sravnitelnyj analiz uslovij formirovaniya i neftegazonosnosti domanikovyh otlozhenij jugo-vostoka Russkoj platformy i slancevyh porod nizhnego paleozoya Sychuanskoj depressii platformy Yanczy Kitaya. Moscow, 154. Available at: http://www.gubkin.ru/diss2/files/Dissertation_LIANG_X.pdf

[11] San Leon Energy zadovolena rezultatom hidrorozryvu v Polshchi. (2014). Available at: http:// shalegas.in.ua/san-leon-energy-zadovolena-rezultatom/

[12] Sobko, A. (2014). Slancevaya revoljuciya v mire: kak ne zaputatsya v cifrah. Available at: http:// www.odnako.org/blogs/slancevaya-revolyuciya-v-mire-kak-ne-zaputatsya-v-cifrah/

[13] Vytvytskyy, Ya. S., Lebeha, O. V. (2016). Svitovyy dosvid vydobuvannya slantsevoho hazu. Naukovyy visnyk IFNTUNH: seriya «Ekonomika ta upravlinnya v naftoviy i hazoviy promyslovosti», 1 (13), 40-52.

[14] Vytvytskyy, Ya. S., Lebeha, O. V. (2017). Vrakhuvannya faktora chasu pry osvoyenni rodovyshch pryrodnoho hazu u slantsevykh porodakh. Visnyk VIEM», 18, 63-74.

[15] Mastepanov, A. M., Stepanov, A. D., Gorevalov, S. V., Belogorev, A. M. (2013). Netradicionnyj gaz kak faktor regionalizacii gazovyh rynkov. Moscow: IC «Energiya», 128. 